\title{
Learning from Problems: Ideas for Pancasila Education Course Design
}

\author{
Eko A Meinarno ${ }^{1}$ \\ AirinYustikarini Saleh ${ }^{1}$ \\ ${ }^{1}$ Universitas Indonesia, Kampus Baru UI, Depok, Indonesia 16424
}

\begin{abstract}
This article is a narrative description of the ideal concept of teaching and learning Pancasila Education Course for undergraduate students. The conceptualization of this concept is made to answer the situation of the current social life in the society, which is no longer in harmony with the values of Pancasila. The ultimate goal of this design is for students to be able to build their own knowledge (constructivism), understanding and embodiment of Pancasila. The learning approach used in this design is problem-based learning, which is selected to develop students' analytical skills in mastering the knowledge needed to understand the problem. This design is intended for students who have cognitively reached the stage of formal operational development.
\end{abstract}

Keywords: Pancasila Education; problem-based learning; undergraduate student

\section{INTRODUCTION}

The teaching of Pancasila Education begins since a child enters formal education, from elementary to university. The philosophical foundation of the teaching of Pancasila Education in higher education is to develop the competence of faithful attitude towards God Almighty and to be able to show religious attitude, uphold humanitarian values in implementing ethics of good life, internalize the spirit of independence, struggles, and entrepreneurship. In the area of skill competence, students are expected to apply logical, critical, innovative, and measurable quality thinking. In addition, students are also expected to be able to demonstrate independent performance in work and to be responsible for the achievement of group performance under their responsibility. Self-evaluation skill is also important to be developed and included in the development of Indonesian people. Based on those competencies, Pancasila Education in universities focuses on the development of Pancasila values to improve the quality of their graduates. The role of Pancasila Education is very strategic in the transmission of knowledge and transformation of attitude and behavior of Indonesian students. This can be done through the learning process of Pancasila Education.

In the effort to increase the quality of graduates and to build the nation's character, there should be an increase and dynamic revision of the materials that follow the continuous development and should also be advanced based on the dynamic change of needs and era, and also the spirit to defend the nation [1]. In order to fulfill that, there should be a change in the 
teaching condition. Currently, the common teaching pattern is the lecturer-oriented pattern. This shows that the lecturer has the responsibility to achieve the learning objectives. As a result, there is a great possibility that the teaching is boring, monotonous and passive.

On the other hand, the Indonesian National Qualification Framework (KKNI) requires that learning should be the responsibility of the students. Furthermore, the issues of Pancasila embodiment discussed in the lectures are often too national or large, and therefore it does not touch the student's daily behavior. Issues such as politics or defense and state security are too prominent to be discussed. Meanwhile, simple issues that exist in daily life are often unsolved, such as the inability to distinguish hoax from true information, thus they actually spread news that is yet clear; or misbehave in public transportation. However, the embodiment of Pancasila values in daily life is still highly needed for the continuity of the life of our nation and state.

In the learning process in universities, also in Pancasila Education, we know that the condition of each student is different, both in terms of experience, educational background, social situation and others. Referring to Piaget's cognitive developmental stages, university students are at the formal operational stage [2]', which allows them to have higher order thinking skills. Students are able to reason hypothetically-deductively to be able to understand abstract concepts and analyze complex problems. In addition, students are able to develop possibility ideas in order to understand the hidden meaning and a richer meaning of a problem. Differences in experience also enable students to be teachers for other students. In relation to the teaching of PancasilaEducation, questions arise about students' ability to know, understand, implement, and to analyze Pancasila. Therefore, to accommodate such cognitive development, it is necessary to design new learning activities that can form critical, analytical, inductive, deductive and reflective thinking (higher order thinking) in learning Pancasila Education.

The design proposed in this lesson is a student-centered teaching pattern. This learning approach emphasizes the role of learners to be active in building their own knowledge, either through independent learning or collaboration with others. One of the methods that use active learning approach is Problem-Based Learning (PBL). Many teachers and researchers have used PBL methods for several subjects such as Biology in high school students [3], and civic education [4,5]. Therefore, this paper wants to theoretically apply PBL in the Pancasila Education.

\section{THEORETICAL BACKGROUND}

\section{Cognitive Development Stages}

Human's thinking process does not enable human to directly process various information from the outside. This thinking ability, called cognitive, develops through several stages. These stages of cognitive developmentt take place from birth to adulthood. Piaget [2] proposes a developmental theory that explains that humans learn things in their environment through their senses. According to Piaget, there are several stages of cognitive development experienced by humans throughout their life. First, the sensorimotor stage (age 0-3 years), new humans are able to use their reflexes and process information from the outside, one by one and 
on a limited basis. This develops to the preoperational stage (3-6 years of age) that allows humans to create the realization of concrete objects in their minds, to understand their selfidentity and things in the environment, to understand the cause and effect relationship and to discover the object differences. Furthermore, the thinking ability of humans develops into higher stages, namely concrete operational (6-11 years), where humans are able to think spatially, find the similarity of objects, group objects, and think inductive and deductively.

The next stage, the formal operational (11-20 years), allows humans to have hypotheticaldeductive reasoning ability to understand abstract concepts and analyze complex problems. At this stage, humans develop the ability to understand possibility ideas and thoughts, understand the hidden messages of a metaphor and allegory, and find richer meanings in literature work. This hypothetical-deductive reasoning capability includes a methodical and scientific approach to solving problems. A man is able to consider all possible relationships and systematically test them, in order to obtain the truth.

At this cognitive development stage, there are two major changes that occur in human's information processing, which includes structural and functional. Structural changes in humans include changes in two things, namely changes in working memory capacity and the addition of the amount of knowledge stored in long-term memory. The changes that occur in working memory capacity makes it easier for teenagers in their final period of the stage to deal with complex problems or decision-making that involve various pieces of information.

The next big change is functional change. This change is a continuous increase in the speed of information processing [2]. In addition, there is also further development in the executive function, which includes selective attention skills, decision-making, inhibitory control of impulse responses, and management of working memory. These skills develop in line with the age development of adolescence.

First year students in universities or college are still classified as teenagers. They have entered the formal operational stage in their cognitive development. Their thinking skills are already at a high stage and are able to analyze complex problems, understand theoretical concepts, identify problems, and solve problems with several solutions that has been analyzed.

Human's stages of cognitive development, especially students, will continue to grow beyond the formal operational stage. Mature human beings enter a new stage of cognitive development, in which they are able to become reflective thinkers [2] or as the successors of Piaget call it, the post-formal thought [2]'. At this stage, human beings are able to deal with inconsistencies, contradictions, and compromises. Another characteristic at this stage is the flexibility of thinking, where humans are able to use different aspects of cognition when needed. In a certain situation, one does not just use formal logical thinking to solve problems. He also needs to use the results of his personal experience, especially when faced with ambiguous situations. The post-formal thought has another characteristic, which is that it is relative. At this stage of cognitive development, one is able to combine intuitions, emotions with logics to help him face situations such as social dilemmas, which are often poorly structured and are emotionally influenced [2,6].

Schaie [2] and Schaie\& Willis [7] also proposed a cognitive developmental stage that looks at the development of intellectual use and cognition in a social context. The development of intellectual use has goals that move from the acquisition of information and skills (what I need to know), to the practical integration of knowledge and skills (how to use 
what I know), until the search of the meaning and purpose of knowledge and skills (why I should know). According to Schaie, university or college students are at the achieving stage, in which they no longer gain knowledge for the sake of knowledge, however, they use what they know to achieve goals, such as in career and family.

\section{Problem Based Learning}

Currently, the learning approach that is considered suitable for the cognitive development of university students is the active learning approach or the learner-centered perspective. This learning approach emphasizes the role of learners to be active in developing their own knowledge, both through independent learning or collaboration with others. McCombs ${ }^{(8)}$ explained that this approach combines the focus on the learners and the learning process. Aspects within the learners are their genetic characteristics, backgrounds, experiences, perspectives, talents, interests, capacities, and their needs. Meanwhile, the focus on learning process includes the knowledge of learning and how it happens; the most effective teaching method that encouragesmotivation; learning process itself; and reaching the highest achievement for all students. These two focuses will inform and encourage decision-making in education.

One of the methods that use active learning approach is the Problem Based Learning. This approach is a process of teaching and learning in the classroom, which is the embodiment of an active learning approach. In this learning situation, students become the center of attention (focus) or student centered. Susanti [3]' explained that this learning method has a unique characteristic, which is that it learns from problems that exist in real life ${ }^{(9)}$ and emphasizes the activity of investigation in order to solve the problem.

There are several steps used in of this learning model, beginning from presenting triggers, identifying problems (concepts and problems), analyzing problems, defining hypotheses, determining, required knowledge, determining learned knowledge, determining knowledge that needs to be learned, discussing learned or acquired knowledge, and reviewing the evaluation of that knowledge [10,11].

Dwiningrum [5] explains that in this process, students are first required to observe a phenomenon. Furthermore, students are asked to record the problems that arise and solve them. In this process, students are expected to be active in identifying the problems that directly appeared or those that are results of the observed phenomenon.

In problem-based learning, the lecturer acts as a facilitator for students' critical thoughts [9]. Lecturers provide students with questions that trigger them to think, direct students to identify the correct problem of a phenomenon. As a facilitator, lecturers have to master the problem and have a guide to lead the discussion that will take place $[9,11]$.

Mastery of the problem includes the ability to identify several isues that arise from the problem that suits the purpose or not. Moreover, lecturers should also be able to identify potential new problems that could come from the result of the students' discussion. Furthermore, the discussion also requires guidance in order to be in line with the desired learning outcome of the lecturer or team of lecturers. Lecturers will direct students to ask questions, prove assumptions and listen to different perspectives among them $[4,9,12,13]$. 
The most common activity in problem-based learning is group discussion. Through group discussions, students are trained to boldly express their opinions about the results of their problem analysis, which starts from their perspectives [11]. Active discussions will help students to recognize various perspectives and open their insights about the problem. Problembased learning provides students with a challenge to search solutions from real-world problems ${ }^{(9)}$, whether conducted individually or in a group. The problems presented in the learning are expected to increase the students' motivation to understand the concepts taught in a course.

The PBL method has many advantages. Trianto [3] stated that problem-based learning activities could help students develop skills in problem-solving and improve intellectual skills (analysis and synthesis). More over, this learning model also provides an opportunity for students to be responsible for their independent learning process [13].

\section{Learning Interaction in Problem Based Learning}

The activeness of learners in building their knowledge, either independently or in collaboration with others, is the focus in the problem-based learning method. The interaction between learners and learning materials, other learners, or with a lecturer as a facilitator occurs frequently in order to build the learners' knowledge. Vrasidas\&Mc Isaac [14] stated that interaction is a process that consists of mutual actions of two or more actors in a certain context.

Based on the type of interaction, Moore [15] stated three types of interactions, namely learner-content interaction, learner-instructor interaction, and learner-learner interaction. A research by Astuti [16] found that student talks occur more than teacher talks in face-to-face learning using problem-based learning method. Moreover, students also do student talks that are responsive, such as answering questions or responding to answers. Furthermore, Astuti [16] also stated that the following learning methods, presentations and class discussions, apparently provide more opportunities for students to speak. In line with the explanation from Weimer [17], the role of the lecturer as a facilitator is mandatory, thus the opportunity for lecturers to speak is less. Moreover, through this learning method, a condition appears where students have to express more than collective perspective and they have to have a goal to develop knowledge, understanding, or their judgment about an issue that is being discussed. Refutations from students on answers given by other students show that a new perspective is being used. Even though there are plenty perspectives in a discussion, generally, the discussion does not go out of topic, thus this shows that they have a goal to develop knowledge about the issue being discussed.

In the problem-based learning process, the outcome of the teaching and learning process does not merely develop the cognitive domain. Other domains such as affective and psychomotor are also awakened. The three domains have a close relationship that can be seen from two sides (Kemp, Morrison \& Ross, 1994). First, a single learning objective may include two to three domains at once. Second, development in the affective domain can precede successful learning in other domains. For example, students need to retain their learning motivation so that they can master certain learning materials or skills. 
The affective domain develops when a student collaborates with others to understand the lesson material. Students do not only speak to express their opinions, however, they also listen and respond to other students' questions. Their communication skills, for example, when they accept their friend's different opinion or respond to their friend's ideas, can be trained through intense interaction. Students also improve their skills to manage emotion and desire when facing an ambiguous discussion situation or when the discussion becomes tense. Independence in completing tasks and the responsibility to complete it could also be values that develop in them.

\section{Operationalization of Pancasila for PBL}

Pancasila Education is one of the general courses studied at all universities in Indonesia. This course is often used as a reference for student character building. The objective of this course is that a student can form a strong and positive character based on Pancasila. From its existence, this course also exists at earlier levels of education, from elementary to high school. Therefore, students have prior knowledge that will be very helpful in the learning process of Pancasila Education in college.

In this article, the study of Pancasila is not in its material. What is viewed is the competence of the Pancasila Education course and Pancasila as a value. This is implemented as an effort to make Pancasila Education easier to comprehend.

The PBL method allows students to use prior knowledge [9] ofPancasila that has been learned in the earlier levels. The implementation of PBL in Pancasila Education is supported by the possibilty of students to integrate it with other situations and knowledge.

The effort is to place Pancasila as a value. This position is easier to translate into more concrete domains, one of it is to determine a more realistic definition $[18,19]$. An obvious step of the realization of Pancasila in the MKWU learning process is by aligning Pancasila values with the competencies from SN Dikti [1] to build assessment indicators (see table 1).

TABLE I. ALIGNMENT OF PANCASILA VALUES AND COMPETENCIES IN SNDIKTI (2016) FOR UNIVERSITIES GENERAL COURSES OF PANCASILA EDUCATION

\begin{tabular}{|c|c|c|}
\hline Pancasila Values & Definition & $\begin{array}{c}\text { Detail of } \\
\text { Competencies }\end{array}$ \\
\hline Ketuhanan Yang MahaEsa (Religio-tolerance) & $\begin{array}{l}\text { Faith in God } \\
\text { and keep His } \\
\text { commandments } \\
\text { according to } \\
\text { belief and not } \\
\text { impose trust on } \\
\text { others }\end{array}$ & $\begin{array}{l}\text { Attitudes: } \\
\text { Deity to the One } \\
\text { God and able to } \\
\text { show religious } \\
\text { attitude } \\
\text { Appreciate } \\
\text { cultural } \\
\text { diversity, views, } \\
\text { religion, and } \\
\text { beliefs, as well } \\
\text { as the original } \\
\text { opinions or } \\
\text { findings of } \\
\text { others }\end{array}$ \\
\hline
\end{tabular}




\begin{tabular}{|c|c|c|}
\hline Pancasila Values & Definition & $\begin{array}{c}\text { Detail of } \\
\text { Competencies }\end{array}$ \\
\hline \multirow{3}{*}{ Kemanusiaan yang adil andberadab (Humanity) } & \multirow{3}{*}{$\begin{array}{l}\text { Recognize } \\
\text { equality of } \\
\text { rights and } \\
\text { duties, } \\
\text { affection to } \\
\text { others, } \\
\text { establish } \\
\text { relationships } \\
\text { with other } \\
\text { nations based } \\
\text { on mutual } \\
\text { respect }\end{array}$} & $\begin{array}{l}\text { Skills: } \\
\text { Able to conduct } \\
\text { self-evaluation } \\
\text { process to the } \\
\text { working group, } \\
\text { which is under } \\
\text { its responsibility, } \\
\text { and able to } \\
\text { manage the } \\
\text { learning } \\
\text { independently. }\end{array}$ \\
\hline & & $\begin{array}{l}\text { Attitudes: } \\
\text { Uphold the value } \\
\text { of humanity in } \\
\text { carrying out } \\
\text { duties based on } \\
\text { religion, morals } \\
\text { and ethics. } \\
\text { Contributing to } \\
\text { the enhancement } \\
\text { of the quality of } \\
\text { life in society, } \\
\text { nation, religion, } \\
\text { and civilization } \\
\text { based on } \\
\text { Pancasila. } \\
\text { Internalize } \\
\text { academic values, } \\
\text { norms, and } \\
\text { ethics. }\end{array}$ \\
\hline & & $\begin{array}{l}\text { Skills: } \\
\text { Able to examine } \\
\text { cases of } \\
\text { application of } \\
\text { science, } \\
\text { technology, art } \\
\text { in accordance } \\
\text { with the field of } \\
\text { expertise in } \\
\text { order to produce } \\
\text { prototypes, } \\
\text { standard } \\
\text { procedures, } \\
\text { design or } \\
\text { artwork. } \\
\text { Able to maintain } \\
\text { and develop } \\
\text { networks of }\end{array}$ \\
\hline
\end{tabular}




\begin{tabular}{|c|c|c|}
\hline Pancasila Values & Definition & $\begin{array}{c}\text { Detail of } \\
\text { Competencies }\end{array}$ \\
\hline \multirow{3}{*}{ Persatuan Indonesia (Patriotism) } & \multirow{3}{*}{$\begin{array}{l}\text { Prioritizing the } \\
\text { interests of the } \\
\text { nation rather } \\
\text { than self / } \\
\text { group, love of } \\
\text { the homeland } \\
\text { and nation and } \\
\text { develop a sense } \\
\text { of unity for the } \\
\text { nation. }\end{array}$} & $\begin{array}{l}\text { cooperation and } \\
\text { cooperation } \\
\text { within and } \\
\text { outside the } \\
\text { institution. } \\
\text { Capable of } \\
\text { documenting, } \\
\text { storing, securing, } \\
\text { and recovering } \\
\text { data to ensure } \\
\text { validity and } \\
\text { prevention of } \\
\text { plagiarism. }\end{array}$ \\
\hline & & $\begin{array}{l}\text { Attitudes: } \\
\text { Serve as a proud } \\
\text { citizen of } \\
\text { Indonesia, } \\
\text { express love for } \\
\text { country, has } \\
\text { nationalism and } \\
\text { responsibility to } \\
\text { the state and } \\
\text { nation. }\end{array}$ \\
\hline & & $\begin{array}{l}\text { Skills: } \\
\text { Able to compile } \\
\text { the results of his } \\
\text { studies in the } \\
\text { form of working } \\
\text { papers, design } \\
\text { specifications or } \\
\text { art essays and } \\
\text { upload them in } \\
\text { university } \\
\text { database }\end{array}$ \\
\hline $\begin{array}{l}\text { Kerakyatan yang } \\
\text { dipimpinolehhikmatkebijaksanaandalampermusyawaratanperwakilan } \\
\text { (Democracy) }\end{array}$ & $\begin{array}{l}\text { Decision- } \\
\text { making based } \\
\text { on } \\
\text { deliberations } \\
\text { for the } \\
\text { common good } \\
\text { by not } \\
\text { imposing the } \\
\text { will of others, } \\
\text { can be } \\
\text { accounted for } \\
\text { and implement } \\
\text { the decisions } \\
\text { taken. }\end{array}$ & $\begin{array}{l}\text { Attitudes: } \\
\text { Obey the law } \\
\text { and discipline in } \\
\text { the life of society } \\
\text { and state } \\
\text { Demonstrate a } \\
\text { responsible } \\
\text { attitude towards } \\
\text { the work in } \\
\text { anown field of } \\
\text { expertise } \\
\text { independently. } \\
\text { Skills: }\end{array}$ \\
\hline
\end{tabular}




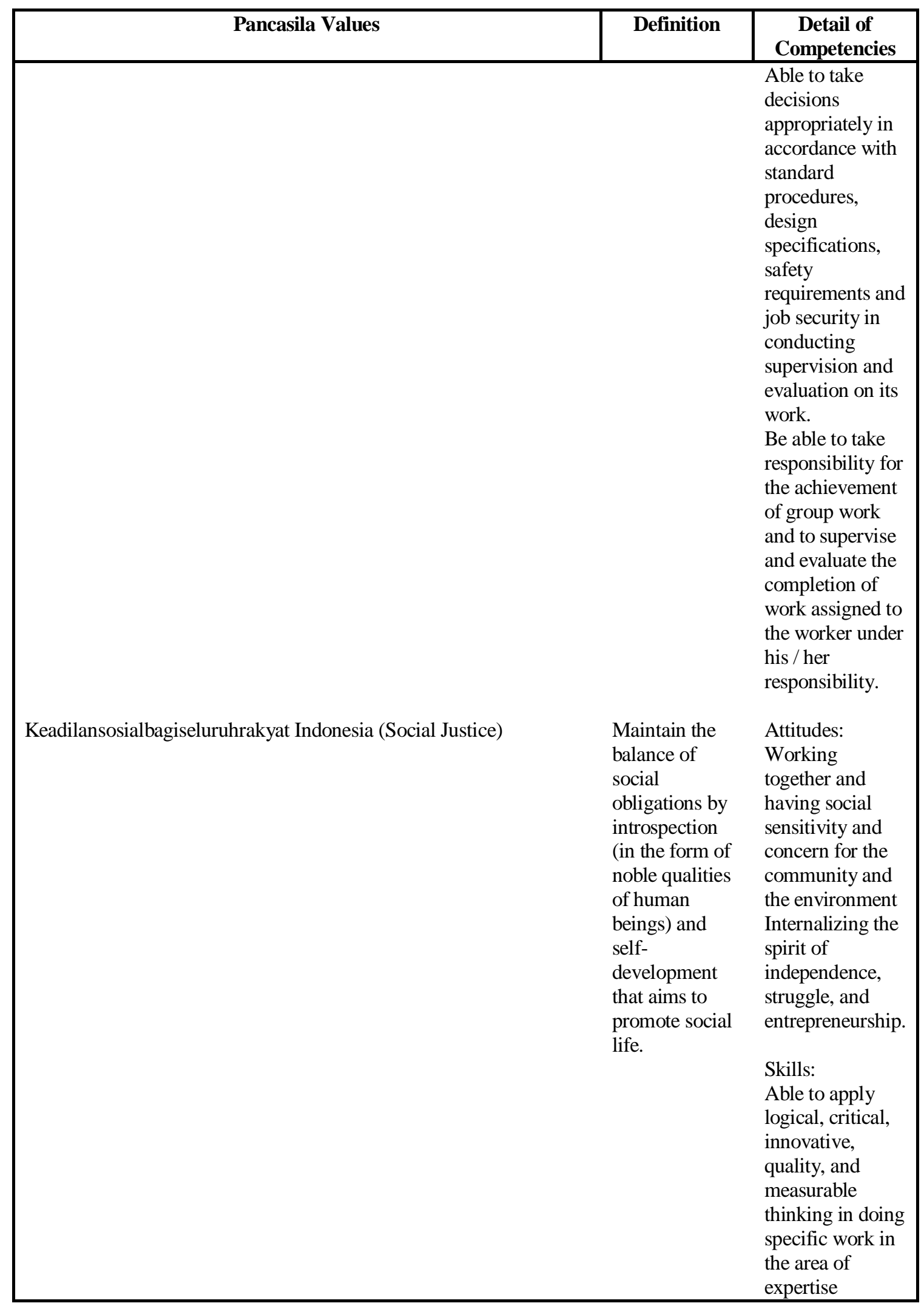




\begin{tabular}{|c|c|c|}
\hline Pancasila Values & Definition & $\begin{array}{c}\text { Detail of } \\
\text { Competencies }\end{array}$ \\
\hline & & $\begin{array}{l}\text { Able to } \\
\text { demonstrate } \\
\text { independent, } \\
\text { quality, and } \\
\text { measurable } \\
\text { performance }\end{array}$ \\
\hline
\end{tabular}

\section{METHOD}

The design of the teaching and learning process is made according to the students' cognitive development stage. By using the basic idea of Piaget's development stages, it is necessary to elaborate the characteristics of formal operational stage and implement them in the learning process.

The classroom is designed for a maximum of 36 students. This amount is important because class activities will be easily observed when the number of participants is not too many. In addition, lecturers will be easier to remember the participants. Thereby, it will be possible to improve the monitoring and assessment of students' performance.

Lecturers can monitor through class discussion observation and the students' assessment of other students. Lecturers and students can conduct monitoring by filling the student assessment form. The assessment aspects in the form are designed based on the comptencies of knowledge, attitude, and SNDIKTI Pancasila Education skills [1]. These aspects are clarity of discussion, communication, responsibility, and effective behavior.

The important aspect in Problem Based Learning is to create a trigger. It is important to create triggers that may enable various perspectives, thus students will explore various areas. The triggers provided are real incidents, such as driving against the flow of traffic, smoking in public areas, responding to false news (hoax), paying taxes, etc.

The first session begins with presenting the trigger. Students are asked to form groups. The group's task is to explore and search for issues that can be learned from the trigger. The learning issues can be obtained from various perspectives. The result of the discussion is a definition of the problem and aspects that need to be known and learned in order to understand the problem. In this session, students will individually search for reading resources. The search can be from the official websites, newspapers, books or even journals. Students produce an independent paper that consists of a summary of the analysis/study about the aspects that need to be known and learned from the problem/trigger. In this session, the role of the lecturer is to monitor the discussion process and to guide students to achieve the suitable learning issue that is in accordance with the design.

In the second session, students present their independent paper and develop shared knowledge based on the definition of each group's problem. The role of the lecturer in this session is to provide oral feedback and to clarify the students' understanding. At the end of this session, all students receive an assessment form about their friends' performance. They will assess the performance of their friends during group discussions. 
In the third session, students collectively search for alternative solutions to the problem that has been agreed by the group. Group discussions are still being conducted and monitored by lecturers. At the end of the session, students fill in an inter-student assessment form, which assessestheir effective performance behavior during group study.

In the fourth session, all groups present the results of their discussions. Lecturers will assess the presentation based on the systematics, language use and attitudes during presentation. This fourth session is the last session for each problem. The role of lecturers in this session is to monitor the discussion and clarify the students' understanding.

The lecturer will assess the group presentation paper. To support the competence of qualified students, the paper assignment is accompanied by the basic capability of information search. Papers are highly valued when the group uses reference materialsfrom national or international journals. Using journals as references aim to develop scientific thinking for students who have just entered college level. The paper assignment encourages the development of students' cognitive abilities, starting from the ability to search articles to problem analysis using arguments based on scientific findings. The assignment also trains students to be more sensitive to hoaxes. In addition, students are trained to re-confirm what has been found and the source that is used.

In one semester this method can beimplemented two to three times. Each activity only discusses one trigger. Therefore, there will be three triggers in Pancasila Education lessons. Lecturers still have enough time to review the materials or remind the learning objectives. This is possible because each Problem Based Learning method only requires three to four sessions. In one semester, generally, PancasilaEducation courses are held in 12-14 sessions.

In the Problem Based Learning method, a final exam at the end of each semester is required. The questions are mainly to evaluate the students' understanding and it is better if the items were essays. The exam questions are based on Bloom's cognitive taxonomy. For university students, the common taxonomy reference used is $\mathrm{C} 4$ or the analysis stage. Essay questions allow lecturers to observe the extent of students' cognitive abilities to relate knowledge of Pancasila with the existing reality. Not to forget is the need of an assessment rubric. Similar to previous assessment rubrics, it still emphasizes on objective aspects.

\section{DISCUSSION}

Pancasila Education, as a General Course of University, has a strategic position for character building. Therefore, the teaching and learning process in Pancasila Education must be viewed holistically and integratively. This is evident from the design that combines an active learning approach that focuses on students, the cognitive development stage, and the embodiment of Pancasila values in teaching and learning activities of Pancasila Education.

The active learning approach that uses real problems is in line with Ehrlich's [4] idea that teaching programs must be attached to something tangible or concrete. Thus, the teaching and learning process cannot be limited to only teach theoretical concepts. Students will have a better understanding of Pancasila materials if they integrate their lessons with tasks that are considered useful for them and the society [4]. In line with students' cognitive development stage, which is the formal operational stage, the Problem Based Learning method is the correct 
method. This is in line with Trianto's [3] view that this method helps students improve their intellectual skills, which are analysis and synthesis.

The implementation of student-focused learning method is considered theoretically adequate and superior, as well as its application. For example, Ehrlich [4] applied the Problem Based Learning method to Civic Education in the United States. Research on students attending the CivicEducation course demonstrates the ability to solve problems for the Human Rights materials [5].

In the discussion sessions, students become trained to be brave to express their opinions. They also learn to accept different points of view [2,11]. This also develops their attitude to respect others [15], which means that students are developing their competencies (table 1).

Another aspect that appears in active learning is a stronger relationship among students. The form of this strong relationship is the frequency of communication during discussions, during presentation in front of the class, and during producing papers. Discussion sessions also enhance social skills, for example, a higher intensity and quality of interpersonal relationships among students [15].

Students can better explore their ability and their group's ability. Upon the first PBL session, students must identify the problem and present it to a group of friends (10). Exploring each idea and searching for information is a part of them building their own building of knowledge. Within the building of knowledge there are contributionsfrom each person. The outcome of this opportunity is a broader learning experience because students do not only learn from resources that they obtained, but also from their friends. Students are more motivated to develop creativity to viewthe learning issues from different perspectives [2].

Translation of competencies based on Pancasila values could help lecturers and students to internalize those values, and it is measurable. Assessment forms based on the translation of values and competencies will facilitate the teaching and learning process. Therefore, lecturers and students can appreciate Pancasila itself.

The outcome of the teaching and learning process is not just to enhance the cognitive. Other aspects are also awakened, such as affective and psychomotor. The psychomotor domain, when students build a product, they certainly have to physically move and search for materials. The affective domain develops when students work together to understand learning issues. It also continues to develop when they appreciate ideas from friends in their group, class friends (pleno), and when they are in a discussion with their lecturer. Moreover, the affective domain also develops when students collaborate in completing their task and when they are responsible to complete the task [12].

Affective domain develops when students work together to understand learning issues. Students not only speak their opinions but also listen and respond to other student's questions (receiving level). In addition, the students also respond to answers from other students to show involvement in discussion. Their skills in communicating, for example when accepting friends' different opinions or responding to others' ideas, can be built through intense interaction during discussion and producing papers (responding level). Neither is the ability to engage in an activity or display a positive or negative attitude towards something (valuing level). The higher level of the affective domain can also be achieved in discussions when students evaluate values, create relationships among values or accept values that apply to a particular group of people (organizing level). Students also improve skills to control emotions 
and encouragement when faced with ambiguous or tensed discussion situations. The independence of doing the tasks and the sense of responsibility for accomplishing the task can also be the values that develop in them [12].

Students' psychomotor domain also develops through discussion and presentation activities, namely when students perform nonverbal communication in presenting the results of individual and group thinking. Nonverbal communications are seen through facial expressions, gestures and body movements in accordance with the topic being discussed.

For example, honesty is needed in the inter-student assessment form, and this is in line with the second principle of Pancasila and with the attitude and skill competencies (table 1). The use of Pancasila in this assessment means that the General Courses of University lecturers also apply Pancasila in class activities. In other words, all class activities are based on Pancasila.

\section{CONCLUSION}

This paper provides a new idea that offers a new learning design in the teaching of Pancasila Education, which can be applied at the higher education level. Student-centered methods are of great variety, however, they all aim to develop students who are capable of critical thinking, analytical, innovative, independent and willing to be a lifelong learner.

\section{REFERENCES}

[1] Buku Ajar Mata Kuliah Wajib Umum Pendidikan Pancasila. (2016). Direktorat Jenderal Pembelajaran dan Kemahasiswaan Kementerian Riset, Teknologi, dan Pendidikan Tinggi Republik Indonesia.

[2] Papalia, D.E., \&Martorell, G. (2015). Experience Human Development 13thed. New York: McGrawHill, Inc.

[3] Harnitayasri, Nurhayati, Irma Suryani. Efektivitas Model Pembelajaran Problem Based Learning (PBL) Terhadap Hasil Belajar Biologi Siswa Pada Materi PencemaranLingkungan Di KelasX SmaNegeri 2 Polewali. JurnalBionature, Volume 16, Nomor 2, Oktober 2015, hlm. 103-109.

[4] Ehrlich, T. (1999). Civic education: Lessons learned. PS: Political Science and Politics, 32(2), 245250.

[5] Dwingingrum, Nr. (2011). Penerapan Model Problem Based Learning Untuk Meningkatkan Hasil Belajar Mata Kuliah Pendidikan Kewarganegaraan Di Program Studi Teknik Mesin Alat Berat Politeknik Balikpapan. JIP (JurnalIlmiahPoliteknik), 2011, 3.1. 36-47.

[6] Sinnot, J.D. (2003) PostformalTought and adult development. In J. Demick\& C. Andreoletti (Eds.), Handbook of adult development. New York: Plenum Press.

[7] Schaie, K.W., \& Willis, S.L. (2000). A stage theory model of adult cognitive development revisited. In B. Rubinstein, M. Moss, \& M. Kleban (Eds.), the many dimensions of aging: Essays in honor of M. Powell Lawton (pp. 173-191). New York: Springer.

[8] McCombs, B. L. (2001). What do we know about learners and learning? The learner-centered framework: Bringing the educational system into balance. Educational Horizons, 182-193.

[9] Hallinger, P., Bridges, EM. (2007). A Problem-based Approach for Management Education: Preparing Managers for Action. Springer. Dordrecht. 
[10] Diponegoro, M., Salim, ES.,Soemiarno, S., Respati, A. (2010). Model pendidikan karakter di universitas Indonesia. Direktorat pendidikan tinggi kementerian pendidikan nasional Indonesia. Jakarta.

[11] De Graaff., Kolmos, A. Characteristics of Problem-Based Learning. International Journal Engineering Education. 2003. Vol. 19. No. 5. pp. 657-662.

[12] Sartono, KE. 2009. Peningkatan pemahaman demokrasi melalui pendekatan problem based learning pada mata kuliah konsep dasar kewarganegaraan S1 PGSD. JurnalllmuPendidikan. Vol. 2, No. 1, Maret 2009. 41-53.

[13] Savery, J. R. (2015). Overview of problem-based learning: Definitions and distinctions. Essential readings in problem-based learning: Exploring and extending the legacy of Howard S. Barrows, 9, 5-15.

[14] Vrasidas, C., \&McIsaac, M. S. (1999). Factors influencing interaction in an online course. American Journal of Distance Education, 13(3), 22-36.

[15] Moore, M. G. (1989). Three types of transaction. Readings in principles of distance education, 100-105.

[16] Astuti, AD. 2015. Perbedaan Pola Interaksiantara Pemelajaran Tatap Muka dan Forum Diskusi Asinkronus dalam Blended Learning di Universitas Indonesia. Skripsi. Universitas Indonesia.

[17] Weimer, M. (2002). Learner-centered teaching: Five key changes to practice. John Wiley \& Sons

[18] Meinarno, EA.,Mashoedi, SF. 2016. Pembuktian Kekuatan Hubungan Antara Nilai-Nilai Pancasila Dengan Kewarganegaraan. Jurnal Ilmiah Pendidikan Pancasiladan Kewarganegaraan. Vol 1, No 1. Juni 2016. Hal. 12-22.

[19] Putri, MA.,Meinarno, EA. Studi Lintas Generasi: Penghayatan Pancasila dan Patriotisme Pada Era Globalisasi. Seminar Nasional Psikologi Indigenous Indonesia 2016: Kebhinekaan dan Masa Depan Indonesia: Peran Ilmu Sosial dalam Masyarakat, Malang, 27-28 Agustus 2016. 